\title{
Shear Strength of Fiber-Reinforced Clayey Sands
}

\author{
Moradi M., "Hamidi A., Tavakoli Mehrjardi Gh.; \\ School of Engineering, Kharazmi University, Tehran, Iran \\ Received: 26 Aug $2013 \quad$ Revised: 30 Dec 2014
}

\begin{abstract}
Consolidated-drained triaxial compression tests were conducted to compare the stress-strain and volume change response of sands and clayey sands reinforced with discrete randomly distributed polypropylene fibers. The influence of various test parameters such as fiber content $(0.0 \%, 0.5 \%$ and $1.0 \%$ by weight $)$, clay content $(0 \%, 10 \%$ and $20 \%$ by weight), relative density (50\% and $90 \%$ ) and confining pressure (100 kPa, $200 \mathrm{kPa}$ and $300 \mathrm{kPa})$ were investigated. It has been observed that addition of clay particles to the sands decreased the shear strength of samples. Also, increase in clay content reduced dilation and increased compressibility of the mixed soil. Addition of the fiber to both sands and clayey sands samples improved the shear strength and increased ductility and axial strain at failure point.
\end{abstract}

Keywords: Clayey sands, fiber reinforcement, triaxial compression test, shear strength.

\footnotetext{
"Corresponding author hamidi@khu.ac.ir
} 


\section{Introduction}

The soil improvement methods are used to improve the soil characteristics in civil engineering projects. One of these methods is using the fibers to increase the strength of soil. Early attempts to increase soil strength by mixing it with other materials date back 3000 years to the construction of Ziggurats (Hamidi and Hooresfand, 2013).

The effect of adding fibers to soils especially sandy soils were examined by many researchers (Maher and Gray, 1990; Consoli et al., 2005, 2007; Park and Tan, 2005; Chauhan et al., 2008; Ahmad et al., 2010; Diambra et al., 2010; Ibrahim et al., 2010; Lovisa et al., 2010; Sadek et al., 2010; Falorca and Pinto, 2011; Liu et al., 2011; Gao and Zhao, 2012; Ibrahim et al., 2012; Plé and Lê, 2012; Singh and Bagra, 2013; Zhang et al., 2014; Wang et al. 2014). Studies showed that the shear strength increases with increasing fiber content. In most construction of road projects, replacement of the soil with high quality materials due to the lack of soils' strength parameters in field is necessary, tends to be very costly. Therefore, the use of fibers and mixing it with the poor soil can be economic and increases the speed of the project's progress, due to removal of the excavation and embankment steps. There are several ways to mixing fibers such as using the layer of fibers in soil or using air pressure to spread fibers in the soil. But one of the simplest method is spread of the fibers on the soil's surface and mixing it with soil by using the graders. 
Different aspects of fiber reinforcements such as content percentage, length, type, orientation angle in soils embankment have been studied by few of researchers (Gray and Ohashi, 1983; Gray and Al-Refaei, 1986; Tavakoli Mehrjardi et al., 2012). According to the results, increase in the length of fibers increased shear strength of fiber-sand composites.

Michalowskia and Čermák (2002) investigated the distribution of fibers in the soil. Three distributions of fibers including random orientation, all fibers in the vertical direction and all fibers in the horizontal direction were investigated. The contribution of the fibers to the composite's strength was the largest when they were placed in direction of the plane with largest tension. Vertical fibers were subjected to compression during triaxial testing. They had an adverse effect on the initial stiffness of the composite and they did not improve the composite's strength. Specimens with randomly distributed fibers exhibited smaller increase in strength than those with horizontal fibers, because a portion of randomly distributed fibers was subjected to compression. Although, the shear strength behavior of fiber-reinforced clayey soils have been studied by others (Tang et al., 2007, 2012; Al-Akhras et al., 2008) but only a limited number of researchers have been examined the effect of adding fiber to clayey sand (Yilmaz, 2009).

The main objective of the work described in this paper is evaluating shear strength of clayey sands in both reinforced and 
unreinforced statuses. A series of consolidated drained triaxial compression tests carried out and peak shear strength, volume change and stiffness characteristics were determined. Special attention was paid to the influences of relative density, confining pressure and fiber content on the stress- strain and volume change behavior.

\section{Materials}

Materials considered in testing program are uniform sandy soil and clay besides polypropylene fibers. Characteristics of each material type are explained in the following sections.

\section{Sand}

A clean and dry, uniform quartz beach sand from the shores of the Caspian Sea (Specifically Babolsar, Iran) was used as the base material in the tests. It has been classified as SP according to the Unified System of Soil Classification. The grain size distribution curve is shown in Figure 1 and properties of the sand are tabulated in Table 1.

\section{Clay}

Kaolinite clay passed No. 200 sieve is used in tests. The clay was obtained from Zunus kaolin mine (Marand, Iran). Clay with three contents of $0 \%, 10 \%$ and $20 \%$ by dry weight of sands were mixed with sands. Figure 1 was shows grain size distribution curve. Also, the characteristics of clay are stated in Table 2. 


\section{Fibers}

Monofilament polypropylene fibers with circular cross section were used throughout this investigation to reinforce soil. Three fiber contents of $0.0 \%, 0.5 \%$ and $1.0 \%$ by dry weight of specimens were used to mix with sands or clayey sands. The physical and mechanical properties of fibers are presented in Table 3 that are similar to those were used by Hamidi and Hooresfand (2013).

\section{Sample preparation and test procedure}

Ladd (1978) method was used for sample preparation. In this method, by knowing the mold's volume and dry density of soils (clay and sand) for different relative density of samples, the required mass of materials is determined. Diameter and height of mold were $100 \mathrm{~mm}$ and $200 \mathrm{~mm}$, respectively and samples were constructed in eight layers. Then, the mass needed for each layer carefully estimated. The required sand and clay for each layer plus 5\% water were mixed by hand. Addition of water makes the sample preparation process much easier with less disturbance. Since, the samples are initially saturated, the initial moisture content will have no effect on the results. Fibers were randomly distributed in the samples according to Michalowskia and Čermák (2002). Fibers were added to soil and mixed by hand to obtain an approximately homogeneous mixture. The finished height of each layer is $25 \mathrm{~mm}$. So, each layer was poured into the mold and compacted by a metal hammer until reaching layer height of $25 \mathrm{~mm}$. 
The samples were prepared in relative densities of $50 \%$ and $90 \%$. Dry density of samples in relative density of $50 \%$ and $90 \%$ were calculated by determining the minimum and maximum dry density of soil in difference clay contents according to ASTM D4253. Consolidated-drained triaxial tests were conducted at confining pressures of 100, 200 and $300 \mathrm{kPa}$ on saturated samples with axial displacement rate of $0.2 \mathrm{~mm} / \mathrm{min}$.

Saturation of specimens was carried out using stepwise back pressure technique in the triaxial equipment. Similarly, the specimen was saturated in two steps, initial and final. In the beginning, saturation was started with a small cell pressure $(20 \mathrm{kPa})$ to remove the entrapped air allowing water to flow at top and bottom of the specimen. Moreover, saturation process continued with a little back pressure $(5 \mathrm{kPa})$ and increment of $5 \mathrm{kPa}$ at a time corresponding to an increased cell pressure level. Finally, the back pressure was stopped at $40 \mathrm{kPa}$ and cell pressure at $50 \mathrm{kPa}$, keeping the effective cell pressure constant $(10 \mathrm{kPa})$. During this process, the saturation was carried out from bottom to top flow by opening the top outlet valve to escape the entrapped air. In this way, the initial saturation was assumed to be completed. Final saturation was involved with real application of back pressure. The top outlet was closed and the sample was saturated with stepwise increase in back pressure and cell pressure keeping the constant effective cell pressure $(10 \mathrm{kPa})$. In this technique, the entrapped air bobbles inside the specimen are supposed to be 
compressed by high pressure applied from the top and bottom of the specimen. In this way, final saturation was stopped when the back pressure reached to $200 \mathrm{kPa}$ level. To ensure saturation of the samples, specimens with B values greater than 0.95 were used in the present study. A membrane with an average thickness of $0.3 \mathrm{~mm}$ was used to be soft enough to minimize the effect of membrane penetration. A computer-controlled triaxial cell was used and an electronic data logger system continuously recorded all data of cell pressure, volume change, load and displacement during the tests. During loading, axial displacement with a precision of $0.01 \mathrm{~mm}$ is measured.

In this study, 54 consolidated drained (CD) triaxial tests on samples with different amounts of clays (0\%, $10 \%$ and 20\%), fibers $(0.0 \%$, $0.5 \%$ and $1.0 \%)$, confining pressures $(100,200$ and $300 \mathrm{kPa})$ and relative densities (50\% and $90 \%$ ), were conducted.

\section{Test results and discussions}

\section{Stress-strain and volume change behavior}

Typical deviatoric stress versus axial strain curves and volume change behavior of unreinforced and fiber-reinforced samples, with different fiber and clay contents in relative densities of $\mathrm{D}_{\mathrm{r}}=50 \%$ and 90\%, are shown in Figure 2 to 7. As can be seen from Figure 2, the deviatoric stress-axial strain curves of sand with $\mathrm{D}_{\mathrm{r}}=50 \%$ shows an apparent peak due to dilative behavior. As clay is added to the sand 
(Figures 3 and 4), stress-strain curves showed ductile behavior and no peak point was observed. The maximum deviatoric stress was defined as that at axial strains of about $20 \%$. In this relative density, clayey sand samples showed full compressive behavior and sandy samples showed a dilative one. Volumetric compression of clayey sand increased with increasing clay fraction and confining pressure.

The reason of this behavior is conceivably due to the replacement of frictional aggregates by cohesive particles, causing reduction in dilative behavior of the composite materials and increased its contractive response. Consequently, by increasing the clay content, the friction between sand grains get reduced (Figure 13) and the cohesion of the mixture was increased (Figure 12), totally resulted in reduction of deviatoric stress at failure state. Although, the sand and clay mixture encountered reduction in bearing pressure compared with sand only, but the ductility of the mixture has been significantly improved.

Increase in relative density to $90 \%$ not only cause the sand samples having the same behavior as samples with $\mathrm{D}_{\mathrm{r}}=50 \%$, but also tends happening an apparent peak point at failure in all stress-strain curves of clayey sand samples and dilative behavior, in either of unreinforced and fiber-reinforced samples (compare Figures 2 to 4 with Figures 5 to 7). In fact, by decreasing the void ratio of the samples, effective stress throughout the mixture could distributed under less compression, resulting in advent of frictional behavior more than the 
loose soil $\left(\mathrm{D}_{\mathrm{r}}=50 \%\right)$. As can be seen, increasing in confining pressure and clay content in samples with $\mathrm{D}_{\mathrm{r}}=90 \%$, increased initial contractive behavior and reduced the residual dilation. Furthermore, Increasing the confining pressure and fiber content make the shear strength of all samples improved in both relative densities.

Figure 8 plots variation of shear strength with change of fiber content, confining pressures and clay content for $\mathrm{D}_{\mathrm{r}}=50 \%$ and $90 \%$. Regard to the obtained results, in both relative densities, sandy samples exhibited the greatest shear resistance. But for clayey sand samples, conceivably, it seems that there is an optimum clay content which gains the maximum shear strength for clayey sand. This maximum value could be different by changing in relative density of the mixture. The authors would propose more investigations on the influence of the clay content in sands precisely to find the reality.

Figure 9 plots variation of axial strain at failure point with change of fiber content, confining pressures and clay content for $\mathrm{D}_{\mathrm{r}}=50 \%$ and $90 \%$. For $\mathrm{D}_{\mathrm{r}}=50 \%$, the results were presented for the sandy soil because no peak point in stress-strain curves of clayey sand was seen at this relative density and failure is considered at axial strain of $20 \%$. On the other hand, ductility of the sand and clay mixtures have been increase as the clay content was increased. It should be notified that in samples with $\mathrm{D}_{\mathrm{r}}=90 \%$, increase in clay content decreased axial strain at failure. Results confirmed that axial strain increased with increase in fiber content and confining pressure. Actually, as fiber content and 
confining pressure are increased, high lateral spreading (owing to higher axial strain) is required to approach the failure status, tending to the high stress mobility in fibres in potential failure plane. This is in agreement with results of Gray and Al-Refeai (1986) who showed that fiber reinforcement increased the axial strain at failure. Since, the strain at failure can be considered as an expression of ductility, therefore, increase in the amount of fiber and confining pressure increased ductility.

\section{Stiffness}

Variations of stiffness- defined as the secant modulus in deviatoric stress-axial strain plot- with change of fiber content, confining pressures and clay content for $\mathrm{D}_{\mathrm{r}}=50 \%$ and $90 \%$ are presented in Figure 10. From this Figure, sandy samples have shown the highest stiffness among the tests and by adding clay, stiffness decreased in clayey sand specimens. Also samples showed more stiffness values in higher confinements. According to Figure 10(a), for relative density of $50 \%$, stiffness of sandy samples decreased with increase in fiber content. However, stiffness of clayey sand specimens can be assumed constant by increase in fiber content. Stiffness of all samples prepared in $90 \%$ relative density decreased by increase in fiber content as can be observed in Figure 10(b). This is in with the line of results stated by several researchers (Gray and Al-Refeai, 1986; Consoli et al., 1998; Hamidi and Hooresfand, 2013). 


\section{Energy absorption}

Energy absorption indicates the amount of energy required to enforce deformations in fiber-reinforced material. It can be defined by calculating the occupied area under stress-strain curve up to a certain axial strain which was $10 \%$ in this study. Figure 11 plots energy absorption for different fiber and clay contents in both considered relative densities. It is obvious that energy absorption was increased by increase of fiber content and relative density from $50 \%$ to $90 \%$. This indicates that more energy is required to cause the mixtures failed with higher relative densities and higher confining pressures.

By comparing the rate of increasing in energy absorption of soils, according to Figures 11(a) and (b), it can be concluded that relative density could have more influence than fiber content.

\section{Shear strength's parameters}

Figures 12 and 13 illustrate variations of cohesion and friction angle, respectively, with change of fiber content, confining pressures and clay content for $\mathrm{D}_{\mathrm{r}}=50 \%$ and $\mathrm{D}_{\mathrm{r}}=90 \%$. As can be expected, increasing clay content of the clayey sand increased cohesion of the specimens and coincidently, reduced the friction angle. Also, cohesion of all specimens and friction angles in most of the samples have been improved as the relative density of the soil had been increased. Moreover, trend of most fiber-reinforced samples was to yield development of an apparent cohesion with an almost linear increment as fiber content was increased. Also increase in fiber content resulted 
in the increase in internal friction angle which has been previously reported by Hamidi and Hooresfand (2013).

\section{Dilation angle}

According to Figures 5 to 7 , the dilatation behavior can be seen in samples densified with $\mathrm{D}_{\mathrm{r}}=90 \%$. Therefore, the dilation angle was calculated and presented in Figure 14 for the different contents of clay, fiber and confining pressure. As can be seen by increasing the confining pressure, dilation angle is reduced. This is due to an increase in grains confinement by increased confining pressure. In addition, by increasing the amount of clay, dilation angle has been expectedly reduced. As it was mentioned before, increasing the fiber content in soil ended to develop apparent cohesion which, in turn, resulted in decrease of dilation angle.

\section{Conclusions}

In present study, shear strength characteristics of fiber-reinforced sand and clayey sand samples have been studied. A number of consolidated-drained triaxial compression tests were carried out and stress-strain and volume change behavior of samples were monitored to evaluate the influence of clay and fiber additions to sands. According to the observations, following results have been obtained:

- In higher relative densities, deviatoric stress-axial strain curves of all sand and clayey sand samples had a peak point and dilation was observed in their volume change response. However, for 
lower relative densities, stress-strain curves of clayey sand samples showed hardening behavior without any distinguished peak point together with compression in volume change behavior.

- Shear strength of sands was obtained more than clayey sand samples and it fell down as clay content was increased. In 50\% relative density, adding $10 \%$ and $20 \%$ clay to sand decreased its shear strength up to $14 \%$ and $22 \%$. Likewise, for $90 \%$ relative density, the rate of reduction was $24 \%$ and $28 \%$ respectively.

- Increase in clay content increased shear strength in lower relative density but it decreased at higher relative density.

- Increase in clay content reduced dilation in volume change behavior, parallelly, getting more compressive strain.

- Both the internal friction angle and cohesion intercept increased with fiber content. For sandy samples reinforced with $1 \%$ fibers, internal friction angle increased from $34^{\circ}$ to $43.4^{\circ}$ for $\mathrm{D}_{\mathrm{r}}=50 \%$ and from $38.8^{\circ}$ to $42.8^{\circ}$ for $\mathrm{D}_{\mathrm{r}}=90 \%$. Adding $10 \%$ clay decreased approximately $5^{\circ}$ of internal friction angle for both relative densities.

\section{Acknowledgments}

The authors would like to acknowledge the efforts of the technicians who assisted during testing. Also, special thanks to IranChina Clay Industries Co. for providing the required clay. 


\section{References}

1. Ahmad F., Bateni F., Azmi M., "Performance evaluation of silty sand reinforced with fibers", Geotextiles and Geomembranes 28 (1) (2010) 9399.

2. Al-Akhras N.M., Attom M.F., Al-Akhras K.M., Malkawi A.I.H., "Influence of fibers on swelling properties of clayey soil", Geosynthetics International 15 (4) (2008) 304-309.

3. Chauhan M.S., Mittal S., Mohanty B., "Performance evaluation of silty sand subgrade reinforced with fly ash and fibre", Geotextiles and Geomembranes 26 (5) (2008) 429-435.

4. Consoli N.C., Casagrande M.D.T., Coop M.R., "Effect of fiber reinforced on the isotropic compression behavior of a sand", Journal of Geotechnical and Geoenvironmental Engineering 131 (11) (2005) 1434-1436.

5. Consoli N.C., Casagrande M.D.T., Coop M.R., "Performance of fiberreinforced sand at large shear strains", Géotechnique 57 (9) 751-756.

6. Diambra A., Ibraim E., Muir Wood D., Russell A.R., "Fibre reinforced sands: experiments and modeling", Geotextiles and Geomembranes 28 (3) (2010) 238-250.

7. Falorca I.M.C.F.G., Pinto M.I.M., "Effect of short randomly distributed polypropylene microfibers on shear strength behavior of soils", Geosynthetics International 18 (1) (2011) 2-11.

8. Gao Z., Zhao J., "Evaluation on failure of fiber-reinforced sand", Journal of Geotechnical and Geoenvironmental Engineering 139 (1) (2012) 95106.

9. Gray D.H., Ohashi H., "Mechanics of fiber reinforcement in sand", Journal of Geotechnical Engineering 109 (3) (1983) 335-353. 
10. Gray D.H., Al-Refaei T., "Behavior of fabric-versus fiber-reinforced sand", Journal of Geotechnical Engineering 112 (8) (1986) 804-821.

11. Hamidi A., Hooresfand, "Effect of fiber reinforcement on triaxial shear behavior of cement treated sand", Geotextiles and Geomembranes 36 (1) (2013) 1-9.

12. Ibrahim E., Diambra A., Muir Wood D., Russell A.R., "Static liquefaction of fibre reinforced sand under monotonic loading", Geotextiles and Geomembranes 28 (4) (2010) 374-385.

13. Ibrahim E., Diambra A., Russell A.R., Muir Wood D., "Assessment of laboratory sample preparation for fibre reinforced sands", Canadian Geotechnical Journal 34 (10) (2012) 69-79.

14. Ladd R.S., "Preparing test specimens using undercompaction", Geotechnical Testing Journal, ASTM 1 (1) (1978) 16-23.

15. Liu J., Wang G., Kamai T., Zhang F., Yang J., Shi B., "Static liquefaction behavior of saturated fiber-reinforced sand in undrained ring shear tests", Canadian Geotechnical Journal 29 (5) (2011) 462-471.

16. Lovisa J., Shukla S.K., Sivakugan N., "Shear strength of randomly distributed moist fibre-reinforced sand", Geosynthetics International 17 (2) (2010)100-106.

17. Maher M.H., Gray D.H., "Static response of reinforced with randomly distributed fibers", Journal of Geotechnical Engineering 116 (11) (1990) 1661-1677.

18. Michalowskia R.L., Čermák J., "Strength anisotropy of fiber-reinforced sand", Computers and Geotechnics 29 (1) (2002) 279-299.

19. Park T., Tan S.A., "Enhanced performance of reinforced soil walls by the inclusion of short fiber", Geotextiles and Geomembranes 23 (4) (2005) 348-361. 
20. Plé O., Lê T.N.H., "Effect of polypropylene fiber-reinforcement on the mechanical behavior of silty clay", Canadian Geotechnical Journal 32 (6) (2012) 111-116.

21. Sadek S., Najjar S.S., Freiha F., "Shear strength of fiber-reinforced sands", Journal of Geotechnical and Geoenvironmental Engineering 136 (3) (2010) 490-499.

22. Singh H.P., Bagra M., "Improvement in CBR value of soil reinforced with jute fiber", International Journal of Innovative Research in science, Engineering and Technology 2 (8) (2013) 3447-3452.

23. Tang C., Shi B., Gao W., Chen W., Cai Y., "Strength and mechanical behavior of short polypropylene fiber reinforced and cement stabilized clayey soil", Geotextiles and Geomembranes 25 (3) (2007) 194-202.

24. Moghaddas Tafreshi S.N., Tavakoli Mehrjardi Gh., Dawson A.R., "Buried Pipes in Rubber-Soil Backfilled Trenches under Cyclic Loading", ASCE, Journal of Geotechnical and Geoenvironmental Eng., 138(11) (2012) 1346-1356.

25. Wang Q., Tang R., Cheng X.W., Fang-ling L., "Research on static triaxial mechanical properties of new cement soil reinforced with polypropylene fiber", Advances in Materials Science and Engineering, http://dx.doi.org/10.1155/2014/532327 (2014).

26. Yilmaz Y., "Experimental investigation of the strength properties of sand-clay mixtures reinforced with randomly distributed discrete polypropylene fibers", Geosynthetics International 5 (1) (2009) 354-363.

27. Zhang C., Zhu H., Shi B., Wu F., Yin J., "Experimental investigation of pullout behavior of fiber-reinforced polymer reinforcements in sand", Journal of Composites for Construction, http://dx.doi.org/10.1061/(ASCE) CC.1943-5614.0000526 (2014). 
Table 1. Physical properties of sandy soil

\begin{tabular}{ll}
\hline Parameters & Value \\
\hline $\mathrm{C}_{\mathrm{u}}$ & 1.23 \\
$\mathrm{C}_{\mathrm{c}}$ & 0.97 \\
$\mathrm{G}_{\mathrm{s}}$ & 2.74 \\
$\mathrm{e}_{\min }$ & 0.60 \\
$\mathrm{e}_{\max }$ & 0.85 \\
$\gamma_{\mathrm{d}, \min }\left(\mathrm{kN} / \mathrm{m}^{3}\right)$ & 14.53 \\
$\gamma_{\mathrm{d} \text { max }}\left(\mathrm{kN} / \mathrm{m}^{3}\right)$ & 16.83 \\
\hline
\end{tabular}

Table 2. Physical properties of clay particles

\begin{tabular}{ll}
\hline Parameters & Value \\
\hline LL & 46 \\
PL & 30 \\
PI & 16 \\
$\mathrm{G}_{\mathrm{s}}$ & 2.65 \\
\hline
\end{tabular}

Table 3. Properties of polypropylene fibers

\begin{tabular}{ll}
\hline Parameters & Value \\
\hline Length $(\mathrm{mm})$ & 12 \\
Diameter $(\mathrm{mm})$ & 0.023 \\
Aspect ratio & 522 \\
Specific gravity & 0.91 \\
Tensile strength $(\mathrm{MPa})$ & 400 \\
Elastic modulus $(\mathrm{MPa})$ & 6000 \\
\hline
\end{tabular}

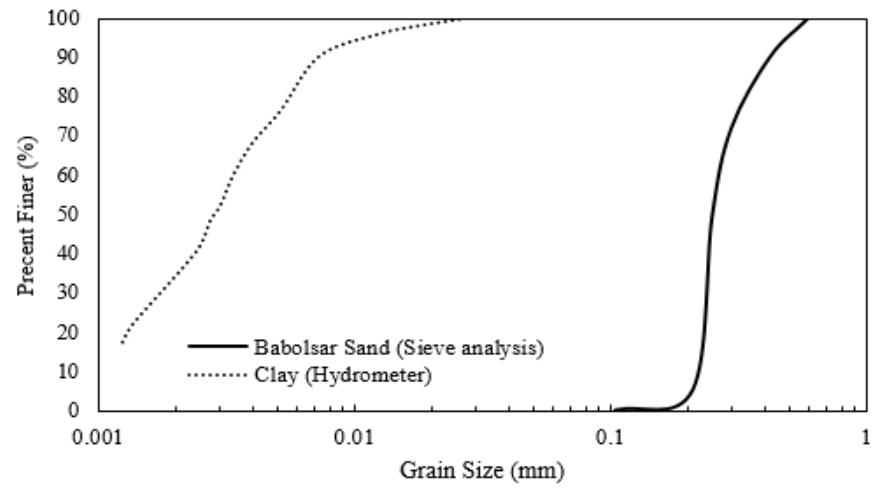

Figure 1. Gradation curve of the sand and clay 

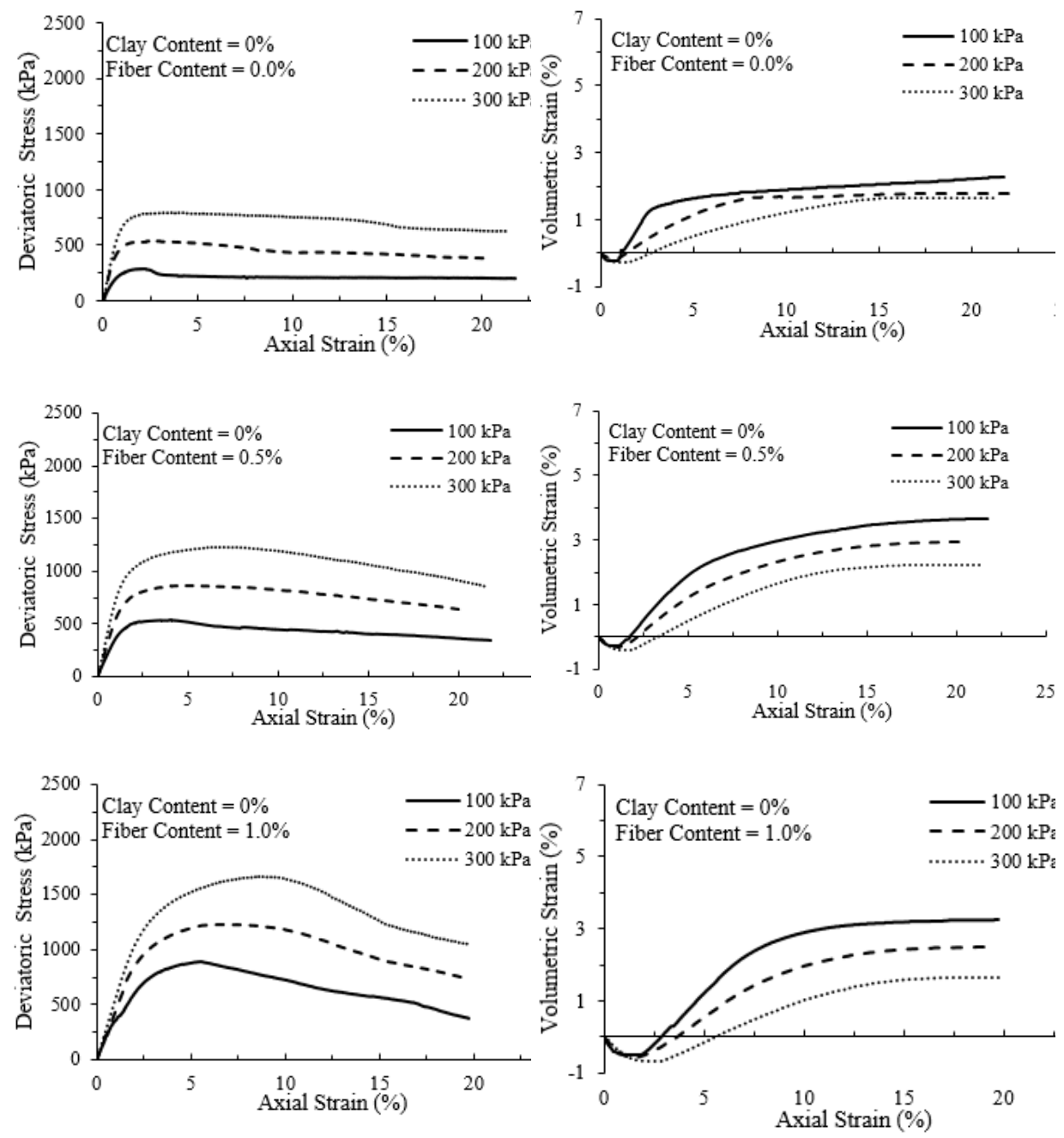

Figure 2. Deviatoric stress-axial strain (on the left) and volumetric strain-axial strain curves (on the right) of unreinforced and fiberreinforced samples with $D_{r}=50 \%$ and clay content $=0 \%$ 

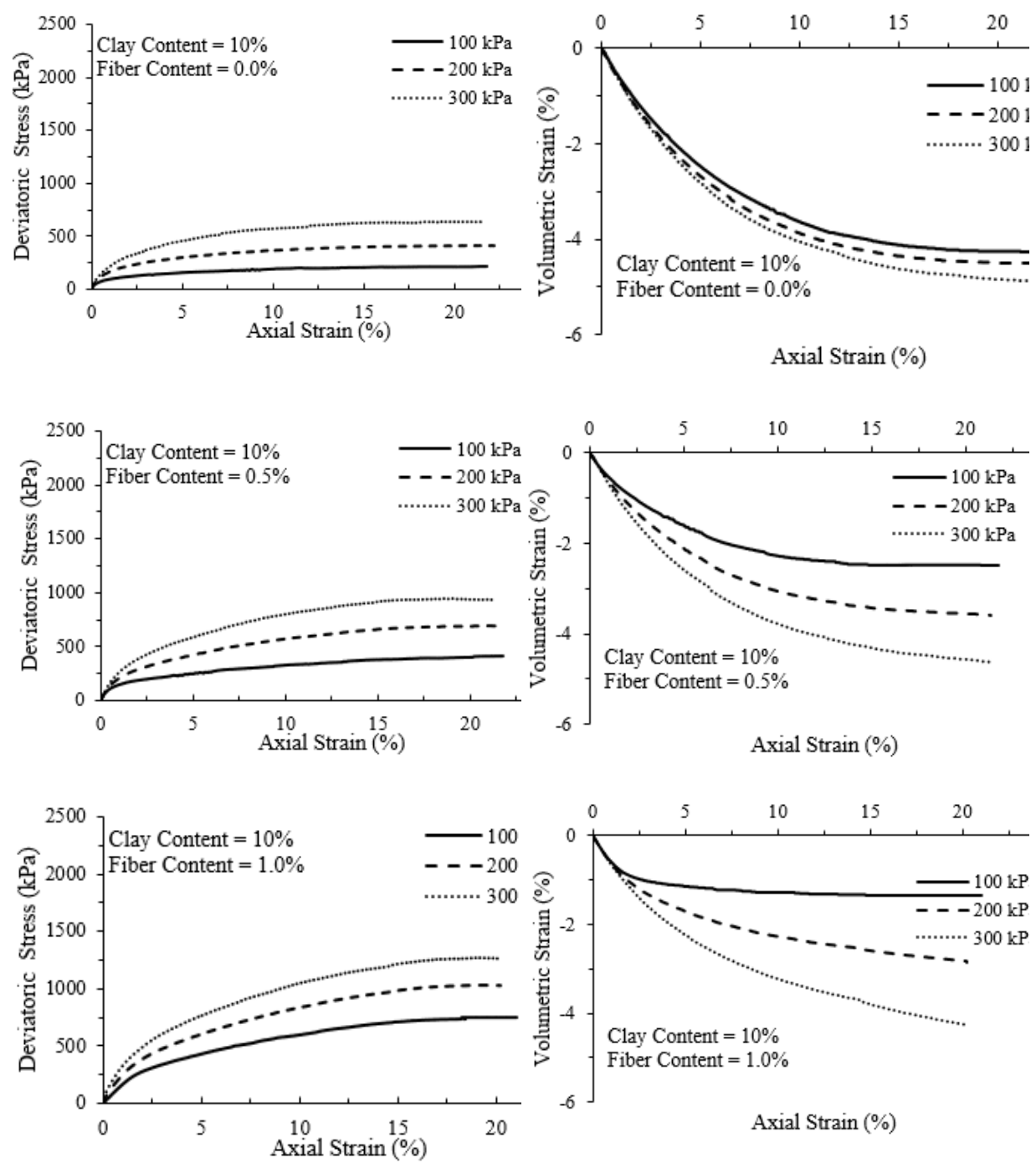

Figure 3. Deviatoric stress-axial strain (on the left) and volumetric strain-axial strain curves (on the right) of unreinforced and fiberreinforced samples with $D_{r}=\mathbf{5 0 \%}$ and clay content $=\mathbf{1 0 \%}$ 

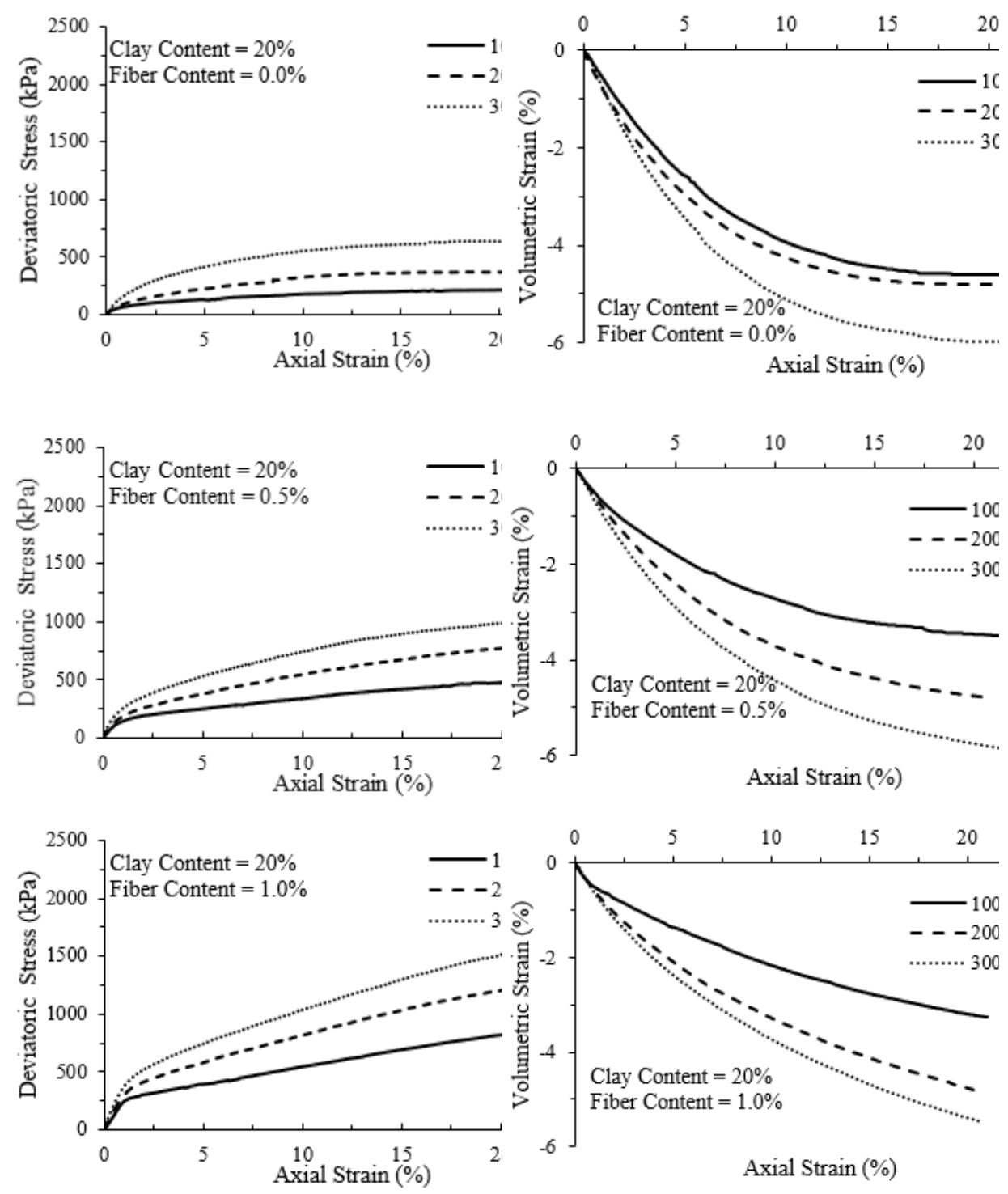

Figure 4. Deviatoric stress-axial strain (on the left) and volumetric strain-axial strain curves (on the right) of unreinforced and fiberreinforced samples with $D_{r}=50 \%$ and clay content $=\mathbf{2 0 \%}$ 

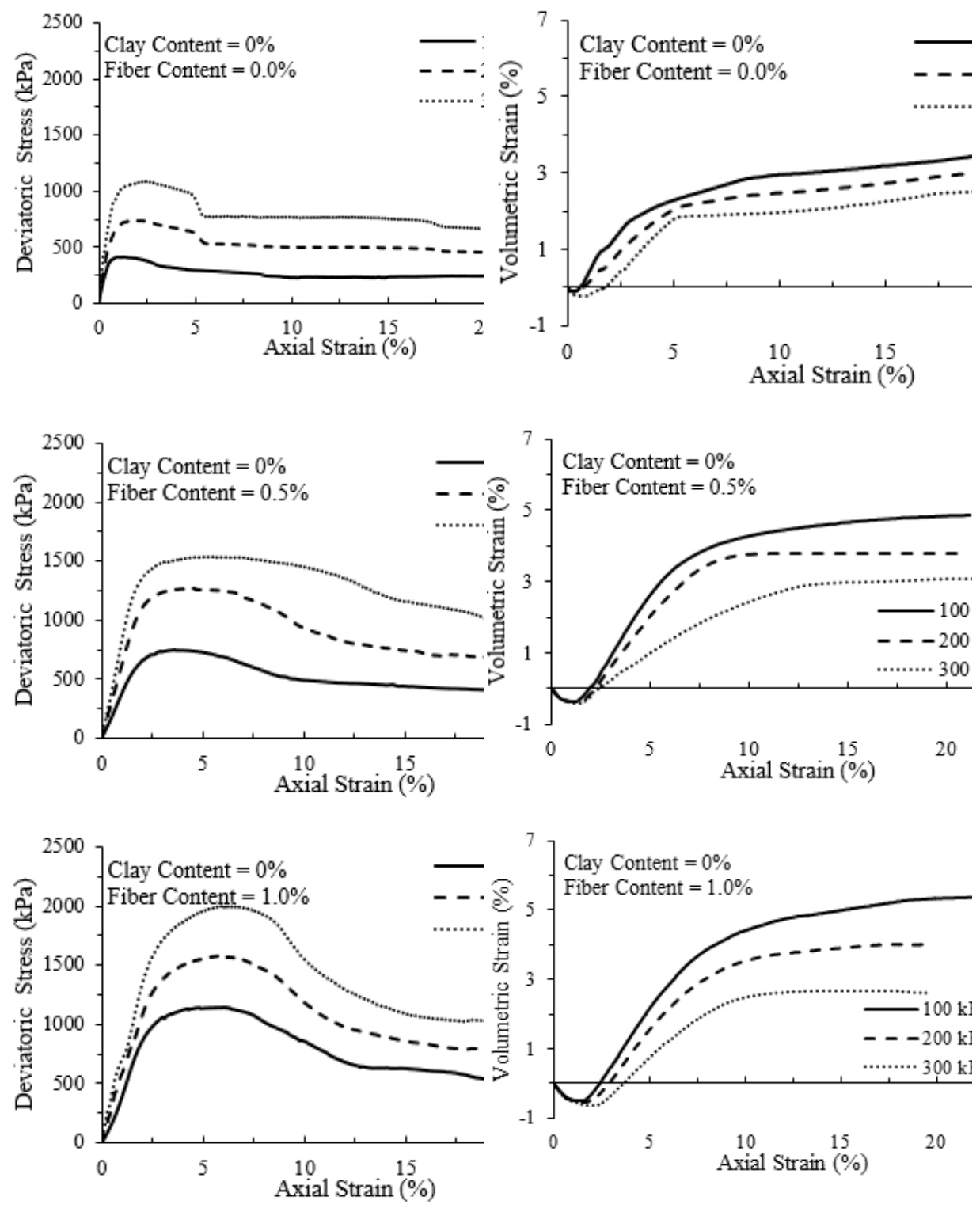

Figure 5. Deviatoric stress-axial strain (on the left) and volumetric strain-axial strain curves (on the right) of unreinforced and fiberreinforced samples with $D_{r}=90 \%$ and clay content $=0 \%$ 

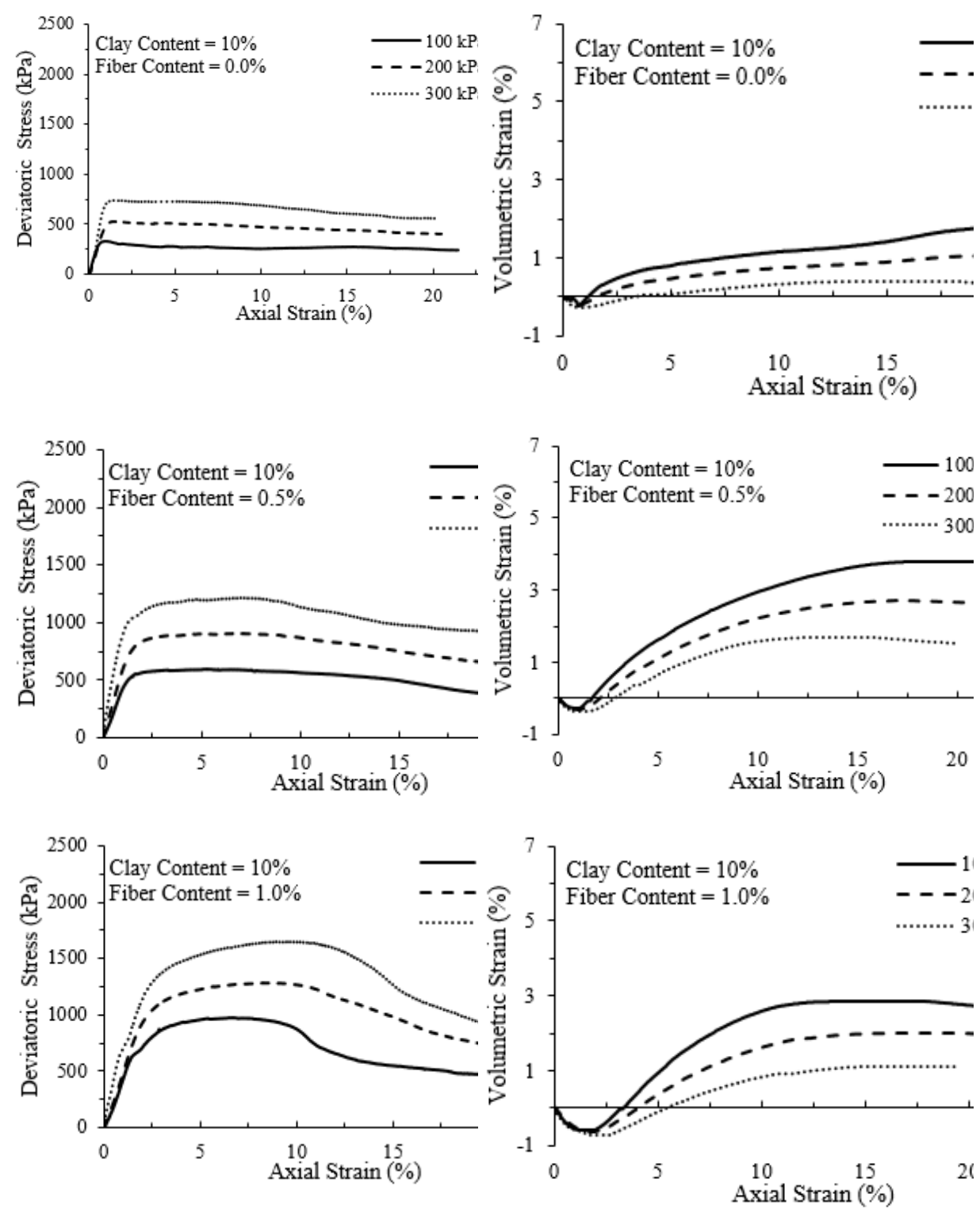

Figure 6. Deviatoric stress-axial strain (on the left) and volumetric strain-axial strain curves (on the right) of unreinforced and fiberreinforced samples with $D_{r}=90 \%$ and clay content $=10 \%$ 

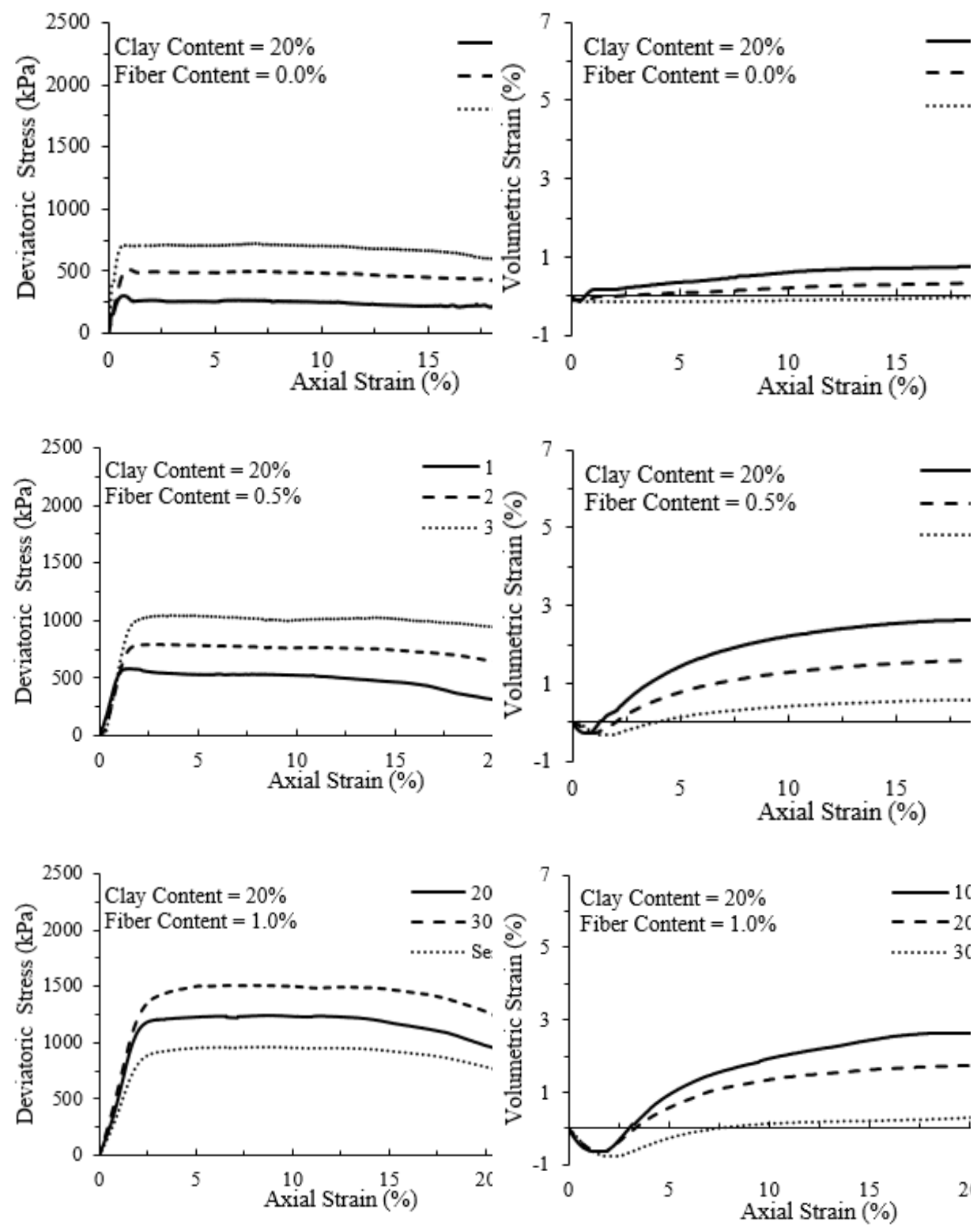

Figure 7. Deviatoric stress-axial strain (on the left) and volumetric strain-axial strain curves (on the right) of unreinforced and fiberreinforced samples with $\mathrm{D}_{\mathrm{r}}=\mathbf{9 0 \%}$ and clay content $=\mathbf{2 0 \%}$ 


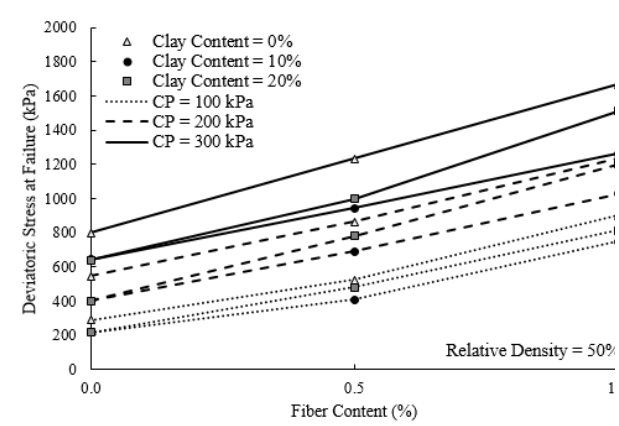

(a)

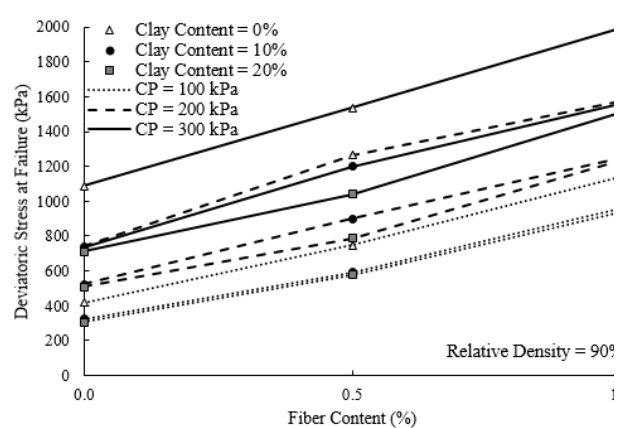

(b)

Figure 8. Variation of shear strength with change of fiber content, confining pressures and clay content for (a) $\mathrm{D}_{\mathrm{r}}=\mathbf{5 0 \%}$ (b) $\mathrm{D}_{\mathrm{r}}=\mathbf{9 0 \%}$

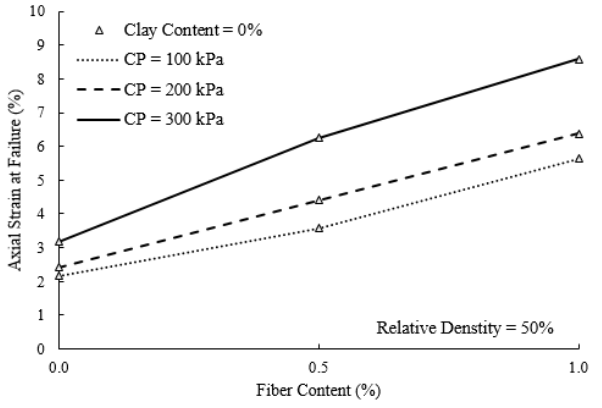

(a)

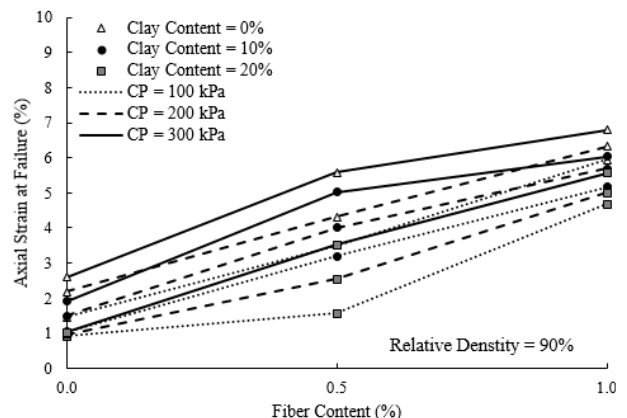

(b)

Figure 9. Variation of axial strain at failure with change of fiber content, confining pressures and clay content for

(a) $\mathrm{D}_{\mathrm{r}}=\mathbf{5 0 \%}$ (b) $\mathrm{D}_{\mathrm{r}}=\mathbf{9 0 \%}$

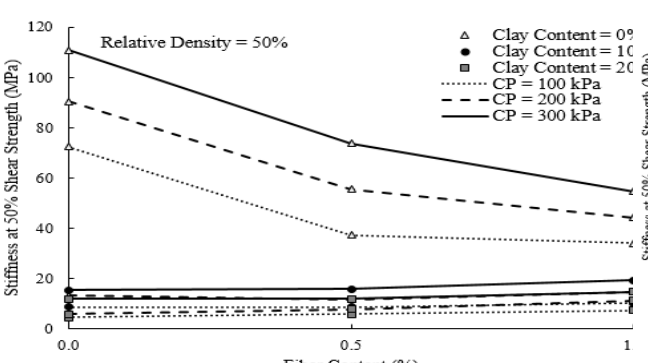

(a)

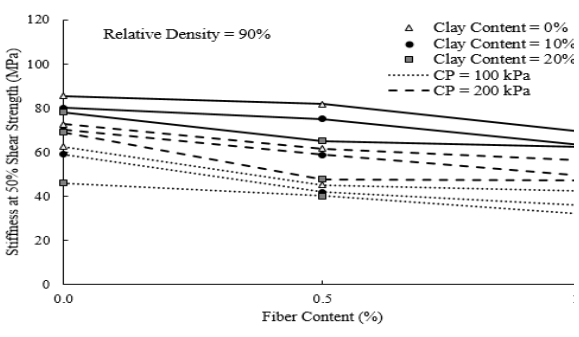

(b)

Figure 10. Variation of stiffness with change of fiber content, confining pressures and clay content for (a) $\mathrm{D}_{\mathrm{r}}=\mathbf{5 0 \%}$ (b) $\mathrm{D}_{\mathrm{r}}=\mathbf{9 0 \%}$ 


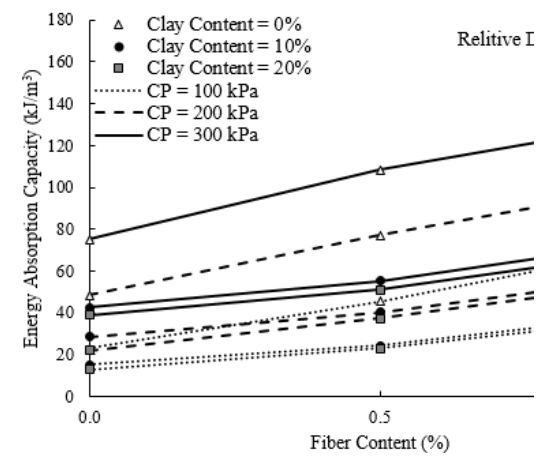

(a)

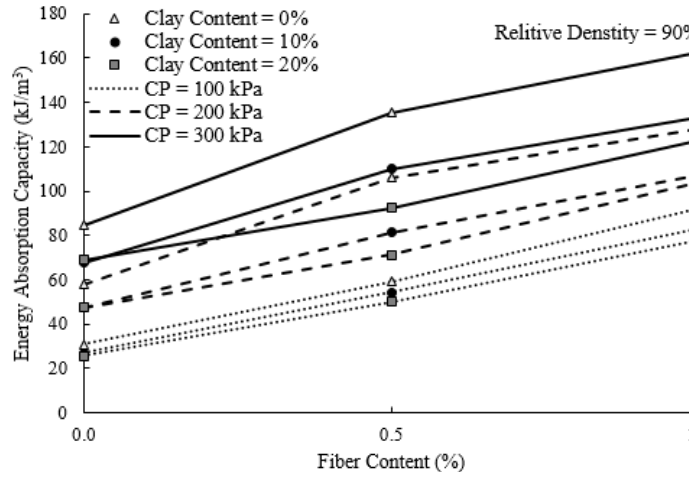

(b)

Figure 11. Variation of energy absorption capacity with change of fiber content, confining pressures and clay content for (a) $\mathrm{D}_{\mathrm{r}}=\mathbf{5 0 \%}$ (b) $\mathrm{D}_{\mathrm{r}}=\mathbf{9 0 \%}$

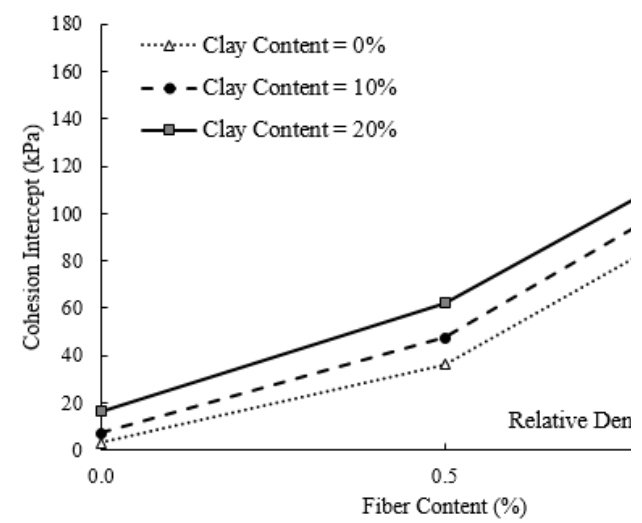

(a)

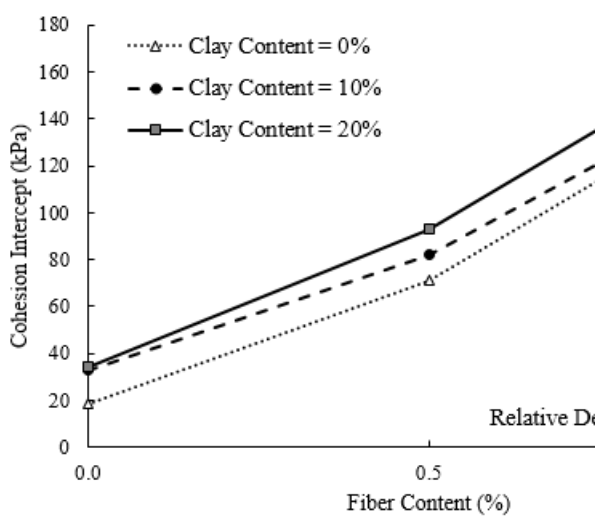

(b)

Figure 12. Variation of cohesion with change of fiber content, confining pressures and clay content for $(a) D_{r}=50 \%$ (b) $D_{r}=90 \%$ 


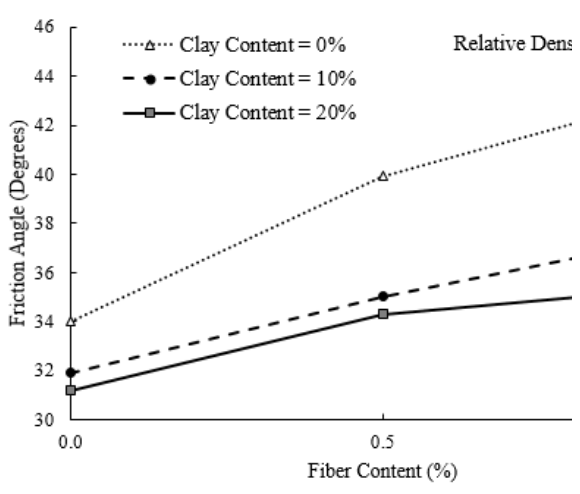

(a)

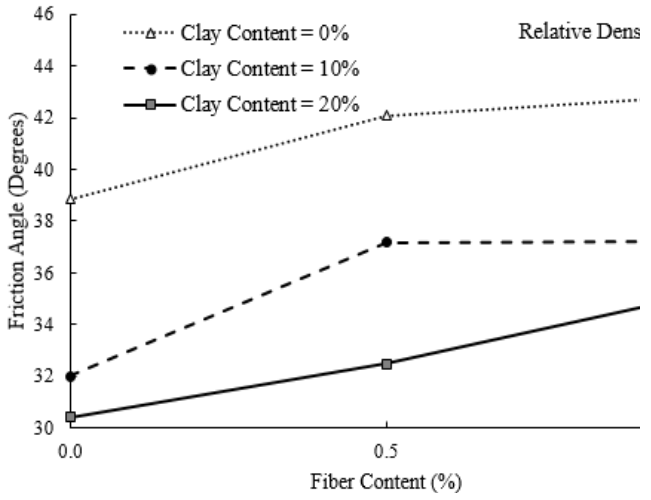

(b)

Figure 13. Variation of friction angle with change of fiber content, confining pressures and clay content for (a) $\mathrm{D}_{\mathrm{r}}=50 \%$ (b) $\mathrm{D}_{\mathrm{r}}=\mathbf{9 0 \%}$

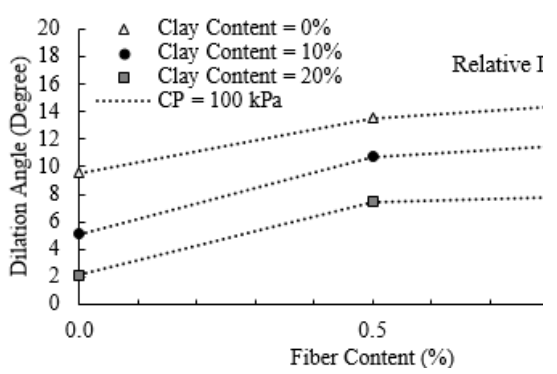

(a)

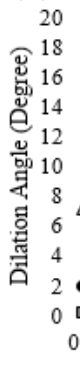

$\triangle$ Clay Content $=0 \%$

- Clay Content $=10 \%$

- Clay Content $=20 \%$

$\mathrm{CP}=300 \mathrm{kPa}$

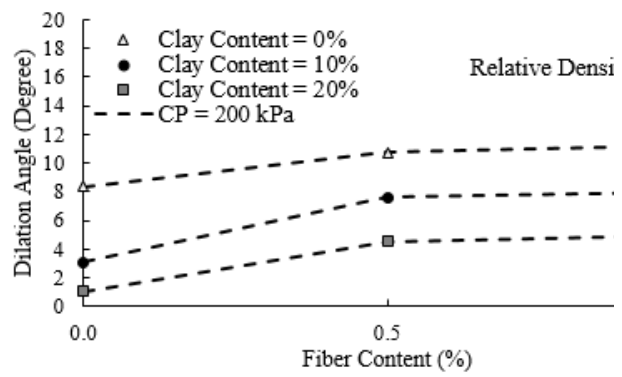

(b)

Relative Density

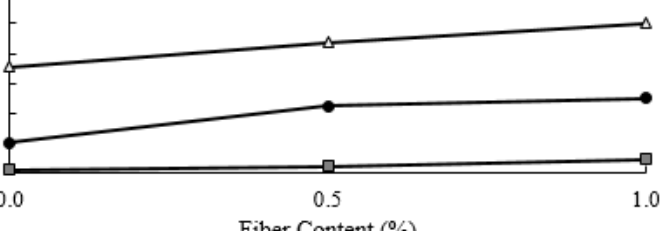

(c)

Figure 14. Variation of dilation angle with change of fiber content and clay content for $D_{\mathrm{r}}=90 \%$ at confining pressures (a) $100 \mathrm{kPa}$, (b) $200 \mathrm{kPa}$ and (c) $300 \mathrm{kPa}$ 